\title{
Linking spatial distributions of sediment diatom assemblages with hydrologi- cal depth profiles in a plateau deep-water lake system of subtropical China
}

\author{
Qian $\mathrm{WANG}^{1}$, Xiangdong YANG ${ }^{1 *}$, Paul B. HAMiLton ${ }^{2} \&$ Enlou Zhang ${ }^{1}$ \\ ${ }^{1}$ State Key Laboratory of Lake Science and Environment, Nanjing Institute of Geography and Limnology, Chinese \\ Academy of Sciences, Nanjing 210008, P. R. China, Graduate School of the Chinese Academy of Science, Beijing \\ 10049, P.R. China ;*corresponding author e-mail:xdyang@niglas.ac.cn \\ ${ }^{2}$ Canadian Museum of Nature, P.O. Box 3443, Station D, Ottawa, Ontario KIP 6P4, Canada; e-mail: phamilton@, \\ mus-nature.ca
}

\begin{abstract}
The spatial distributions of approximately 160 diatom taxa from surface sediments of the plateau deep-water Lugu Lake were investigated. The results exhibited a change in the sediment diatom composition with increasing water depth. The main patterns of variation, derived from a principal component analysis (PCA) and detrended correspondence analysis (DCA), showed that diatom community composition was divided into three depth gradients (near-shore zone; mid-depth zone; profundal deep zone). With increasing depth, the pattern of predominantly periphytic taxa in the shallow waters changed to planktonic assemblages dominated by Cyclotella ocellata, Asterionella formosa and Cyclostephanos dubius. Diatom species diversity decreased from the shallow near-shore zone to the deeper open waters. In addition, there was an increase in the ratio of planktonic to periphytic diatoms at depths $>30 \mathrm{~m}$. These distinct spatial patterns in diatom distribution are clear markers of current water levels within Lake Lugu and represent a benchmark for evaluating paleolimnological changes in water levels, which can be an indirect proxy of regional climate in this monsoon region of southern Asia.
\end{abstract}

Key words: benthic, diatom assemblages, pelagic, plateau lake, spatial distribution, subtropical, water depth

\section{Introduction}

Freshwater diatom assemblages are highly diverse and ubiquitous, and consistently correlate with environmental variables such as lake depth (e.g. YANG \& Duthie 1995; Moser et al. 2000; Wolin \& STONE 2010; Larid et al. 2011). Due to their silica-based shell, they typically preserve well in sediments and have been widely used to reconstruct paleo-environments and past changes in climate (SMol \& Stoermer 2010, publications within). Current models developed with diatom assemblages and environmental relationships, have been focused on the effect of modern anthropogenic activities like lake eutrophication as environmental stressors (e.g. HALL \& SMOL 2010). The global human footprint now covers $83 \%$ of the earth's landmass and it is becoming impossible to exclude local anthropogenic stressors from regional climate change assessments (SANDERSON et al. 2002). For instance, sediment diatom assemblages in deep-water plateau lakes and reservoirs can act as markers for water-level changes related to either natural or anthropogenic disturbances. The key is to identify the nature of these natural or anthropogenic disturbances and assess the interactions between these stressors.

The diversity of living conditions and habitat selection for diatom taxa augments the power of these organisms as a monitoring tool for environmental change. Differences in the life-forms (e.g. planktonic and non-planktonic diatom ratios) have been used for reconstructions of lake-level changes (BARKer et al. 1994; YANG \& DuthiE 1995; LotTer \& Bigler 2000; Moos et al. 2005). Changing water levels in a lake will alter the number and diversity of microhabitats. More microhabitats, like boulder to cobble littoral zones and macrophyte communities in shallow waters, will favour benthic and tychoplanktonic diversity. In contrast, a substantive increase in water volume will decrease the availability of microhabitats favouring a dominated pelagic habitat with planktonic taxa (Wolin \& Stone 2010). When pelagic and benthic species accumulate in lake sediments, the 
paleo-signals from multiple habitats should help explain the changes in past water-levels. Therefore recognizing the relative contributions of diatoms assemblages from microhabitats, especially from larger aquatic riverine and lake systems, is important.

Previously, YANG \& DuthIE (1995) proposed that depth, was a strong controlling variable on sedimentary diatom distribution. The correlation between diatom assemblages and water depth has been well established, and multiple lake depth calibrations have been developed for down-core reconstructions (e.g. BRUGAM et al. 1998; MOSER et al. 2000; Shinneman et al. 2010; Wolin \& STONE 2010; LAIRD et al. 2011), whereas a number of diatom studies have also developed single-lake calibration sets across a water-depth gradient to infer past changes in lake level (YANG \& DuthIE 1995; Brugam et al. 1998; Nguetsop et al. 2004; Moos et al. 2005). Stone \& Fritz (2004) used threedimensional modeling of habitat areas to further assess the planktonic:benthic diatom ratios in relation to water depth. In addition, BARKER et al. (1994) have also used habitat classes of diatoms to reconstruct past lake levels in a groundwaterfed lake in the Atlas Mountains of Morocco.

Lugu Lake, located in Yunnan province of southwest China, is a freshwater aquatic system which is impacted by the southwest monsoons and may represent a good system for paleo-environment and climate reconstructions. At present, little is known about the relationship between the diatom assemblages and their sediment composition. Therefore, the aim of this study was (a) document the spatial distribution of sedimentary diatom deposition in surface-sediment samples along the water-depth gradient; (b) analyze the relationships of species distribution and species diversity with the increasing water depth; (c) calculate depth optima and tolerances for the diatom assemblages of Lugu Lake.

\section{Study area}

Lugu Lake is a typical seasonally-closed deep-water lake located at the boundary between Ninglang County of Yunnan Province and Yanyuan County of Sichuan Province $\left(27^{\circ} 41^{\prime}-27^{\circ} 45^{\prime} \mathrm{N}, 100^{\circ} 45^{\prime}-100^{\circ} 50^{\prime} \mathrm{E}\right)$, southwest China (Fig. 1). It is one of the deepest plateau freshwater lakes in the region with a surface area of $\sim 50.5 \mathrm{~km}^{2}$, maximum water depth of $\sim 93.5 \mathrm{~m}$, average water depth of $\sim 40.4 \mathrm{~m}$, and altitude of $2685 \mathrm{~m}$ a. s. 1. (JI \& FAN 1983). Lugu Lake is located along the edge of the southern Asian rain belt and affected by southwest monsoons from the Indian Ocean and southeast monsoons from the Pacific Ocean (Goswami \& Ajayamohan 2001; Kemball-CooK \& Wang 2001). The climate in this region is temperate with distinct dry and wet seasons; mean air temperature $12.8^{\circ} \mathrm{C}$ and mean annual precipitation $1000 \mathrm{~mm}$. Macrophytes were partly absent from the lake, allowing for the collecting of surface sediments in shallow waters. Terrestrial vegetation in the lake catchment area was dominated by the conifers Pinus yunnanensis var. faranch and Pinus tabuliformis.

Lugu Lake is fed from precipitation and ephemeral streams with the Gaizu River draining from the southeast corner of the lake into the Yalong River (a tributary of Yangtze River). The lake is seasonally isolated from September to May and connected to the Gaizu River mainly in the rainy season (JI \& FAN 1983; YANG 1984). Thus the exogenous components of the autochthonous sediment load originate from weathered crust around the lake basin (ZHANG et al. 1997). Such conditions typically provide natural stratigraphic sedimentary units for investigating paleo-climatic change (WANG \& LI 1991).

\section{Materials and Methods}

\section{Collection of surface-sediment diatom samples}

A series of surface-sediment samples ( topmost $1 \mathrm{~cm}$ ) were collected in August 2010 (Fig. 1). Surface-sediment samples were collected at approximately $1 \mathrm{~m}$ water-depth intervals from 0-10 m, $2.5 \mathrm{~m}$ water depth intervals between $10-20 \mathrm{~m}$, and every $\sim 5 \mathrm{~m}$ for $>20$ $\mathrm{m}$ water depths. Sampling sites were determined with GPS (Garmin eTrex Legend H). A total of 43 samples were collected. Sediment samples for diatom analyses were processed with $10 \%$ HCL to remove carbonates, followed by cold $30 \%$ hydrogen peroxide to oxidize organic matter (BATTARBEE 1986). Diatom valves were identified and counted using differential interference contrast optics (DIC) on an Olympus BX51 microscope with a $100 \mathrm{x}(\mathrm{NA}=0.17)$ objective giving a final magnification of $1000 \times$. A minimum of 500 diatom valves per slide were enumerated in each sample. Diatoms were identified to the species level or lower, primarily using standard European and North American references (KRAMMER \& LANGE-BERTALOT 1986, 1988; 1991a, b; PATRICK \& ReIMER 1966). The taxonomy was corrected to current conventional names based on the Catalogue of Diatom Names (FourTANIER \& KocIOLEK 2011). Diatom species abundance was expressed as percentage of the total sum of all diatoms counted in each sample.

\section{Physical and chemical monitoring}

Integrated water samples were collected from the top 5 $\mathrm{m}$ of the water column in August, 2010 corresponding to the surface sediments collection. Forty-three water 
Table 1. Physical and chemical characteristics of the water column and associated sediment characteristics measured for 43 sampling sites in Lugu Lake in August, 2010 ( $n=43)$.

\begin{tabular}{|c|c|c|c|c|c|}
\hline Variable Name & Units & Min & Max & Mean & Median \\
\hline Depth & $\mathrm{m}$ & 1 & 90 & 32 & 28 \\
\hline Temperature (T) & ${ }^{\circ} \mathrm{C}$ & 18.66 & 22.46 & 21.29 & 21.39 \\
\hline Conductivity (COND) & $\mu \mathrm{S} . \mathrm{cm}^{-2}$ & 2 & 210 & 190 & 206 \\
\hline $\mathrm{pH}$ & & 8.47 & 9.33 & 9.08 & 9.15 \\
\hline Dissolved Oxygen (DO) & $\mathrm{mg} . \mathrm{l}^{-1}$ & 6.61 & 8.65 & 7.51 & 7.48 \\
\hline Total phosphorus (TP) & $\mu \mathrm{g} .1^{-1}$ & 19 & 87 & 50 & 46 \\
\hline Total Nitrogen $(\mathrm{TN})$ & $\mu \mathrm{g} .1^{-1}$ & 80 & 309 & 145 & 129 \\
\hline Chlorophyll- $a($ Chl- $a)$ & $\mu \mathrm{g} .1^{-1}$ & 0 & 0.7 & 0.1 & $<0.1$ \\
\hline Silicate $\left(\mathrm{SiO}_{2}\right)$ & mg..$^{-1}$ & 0.00043 & 0.00179 & 0.00082 & 0.00079 \\
\hline Carbonate $\left(\mathrm{CO}_{3}\right)$ & mg..$^{-1}$ & 12.0 & 24.0 & 12.8 & 12.0 \\
\hline Bicarbonate $\left(\mathrm{HCO}_{3}\right)$ & $\mathrm{mg} . \mathrm{l}^{-1}$ & 36.6 & 158.3 & 78.6 & 73.2 \\
\hline \multicolumn{6}{|l|}{ Sediment parameters } \\
\hline Grain size(GS) (d (0.5)) & $\mathrm{mm}$ & 3.6 & 19.3 & 8.3 & 7.4 \\
\hline Loss on Ignition (LOI) & $\%$ & 4 & 16 & 11 & 11 \\
\hline
\end{tabular}

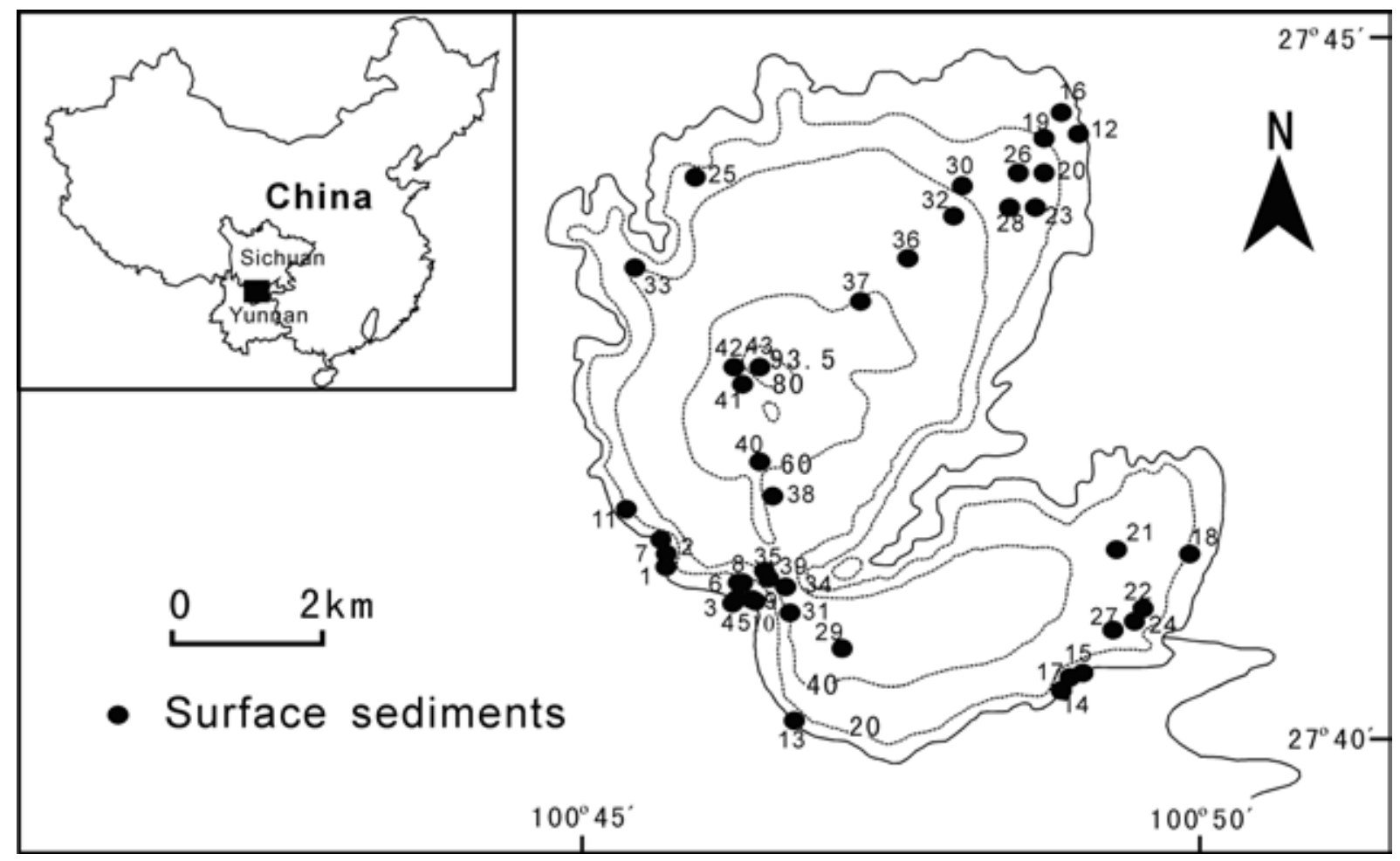

Fig. 1 Geographical map of China highlighting the provinces of Sichuan and Yunnan along with the location of Lugu Lake. The expanded bathymetric map of Lugu Lake shows the general location of the sites sampled for surface-sediments along a water-depth gradient. Regional insert map reprinted with permission. Google map of region 2011. (DMTI Spatial Inc. 2003; Google Earth ${ }^{\mathrm{TM}}$ Mapping Service 2007). 
Table 2. Matrix of Pearson correlation coefficients

\begin{tabular}{|c|c|c|c|c|c|c|c|c|c|c|c|c|}
\hline & Depth & $\bar{T}$ & COND & $\overline{\mathrm{pH}}$ & ORP & DO & $\mathrm{TP}$ & $\mathrm{TN}$ & Chl- $a$ & $\mathrm{SiO}_{2}$ & $\mathrm{CO}_{3}$ & $\mathrm{HCO}_{3}$ \\
\hline Depth & 1 & & & & & & & & & & & \\
\hline $\mathrm{T}$ & -.066 & 1 & & & & & & & & & & \\
\hline COND & -.113 & .080 & 1 & & & & & & & & & \\
\hline $\mathrm{PH}$ & -.292 & .087 & .285 & 1 & & & & & & & & \\
\hline ORP & .018 & .138 & .102 & -.055 & 1 & & & & & & & \\
\hline DO & .038 & -.036 & -.203 & -.005 & .155 & 1 & & & & & & \\
\hline TP & $-.419(* *)$ & .109 & .069 & .143 & -.212 & -.109 & 1 & & & & & \\
\hline $\mathrm{TN}$ & .121 & -.130 & $-.307(*)$ & .107 & -.088 & -.117 & -.290 & 1 & & & & \\
\hline Chl- $a$ & -.081 & .118 & .122 & $.335\left(^{*}\right)$ & .020 & -.113 & .043 & .055 & 1 & & & \\
\hline $\mathrm{SiO}_{2}$ & .218 & -.278 & $-.406(* *)$ & -.083 & -.053 & .208 & -.094 & .282 & -.156 & 1 & & \\
\hline $\mathrm{CO}_{3}$ & .180 & -.012 & .021 & -.018 & -.118 & .013 & .168 & -.075 & .059 & 020 & -.132 & \\
\hline $\mathrm{HCO}_{3}$ & .129 & -.069 & .103 & -.097 & .293 & .071 & .047 & -.101 & -.243 & -.114 & .079 & 1 \\
\hline
\end{tabular}

samples were collected during the August sampling period. Water depth, water temperature, dissolved oxygen (DO), $\mathrm{pH}$ and conductivity were measured in the field using a YSI 650 multi-parameter display system (650 MDS, YSI Incorporated 1700/1725 Brannum Lane, Yellow Springs, OH 45387 USA) with a 600XL probe. Additional chemical variables were measured in the laboratory using the water samples collected. Total nitrogen (TN), total phosphorus (TP), concentration of $\mathrm{HCO}_{3}{ }^{-}$and $\mathrm{CO}_{3}{ }^{2-}$, Chlorophyll- $a(\mathrm{Chl}-a)$ and silica (Si) were analyzed at Nanjing Institute of Geography and Limnology. Methods are outlined in Water and Waste water Monitoring Methods (2002). Grain size of surface sediment samples was measured with a Mastesizer-2000 laser diffraction particle size analyzer (made in England by Malvern Instruments Ltd.) and loss-on-ignition (LOI) was analyzed according to the method of HeIri et al. (2001).

\section{Data analysis}

A total of 160 diatom taxa (including subspecies and varieties) were identified during the study. Fifty-five taxa, with a relative abundance greater than $1 \%$ in at least one sample, were used in subsequent analyses. In order to investigate the change in diatom composition of the surface-sediment data, an indirect ordination technique of detrended correspondence analysis (DCA) with detrending by segments and down-weighting of rare taxa was performed. Patterns in the diatom distribution were evaluated and the maximum amount of variation within the species composition was determined (TER BRAAK 1995). The gradient length of the main DCA ordination axes indicated whether linear- or unimodal-based numerical techniques were appropriate for the analyses (TER BraAK \& Prentice 1988). The gradient lengths ( $<2.0$ standard deviation (S.D. units)) for the first DCA axis suggested that the species data were behaving in a linear manner, so a linear ordination technique (Principal Component Analysis (PCA)) was subsequently employed to analyze the distribution of surface sediment diatom assemblages (BIRKS 1995). Percent diatom data were square root transformed prior to numerical analyses in order to stabilize variances and $\log$ transformations were used for environmental variables (except for $\mathrm{pH}$ ). Direct gradient ordination by redundancy analysis (RDA) and Monte Carlo permutation tests with 999 permutations were used to determine environmental variables that explained significant $(p \leq 0.05)$ patterns in the diatom distribution. Ordinations were performed using the program CANOCO version 4.5 (TER BraAK \& ŠmilaUer 2002).

A constrained cluster analysis was performed on the diatom data to determine assemblage zones using a squared-chord distance as a measure of dissimilarity with the program CONISS and diagrams were constructed using TILIA and TGView 2.02 (GRIMM 1990, 2004). Diversity indices for diatom species data were calculated with the PAST statistical software (HAMMER 


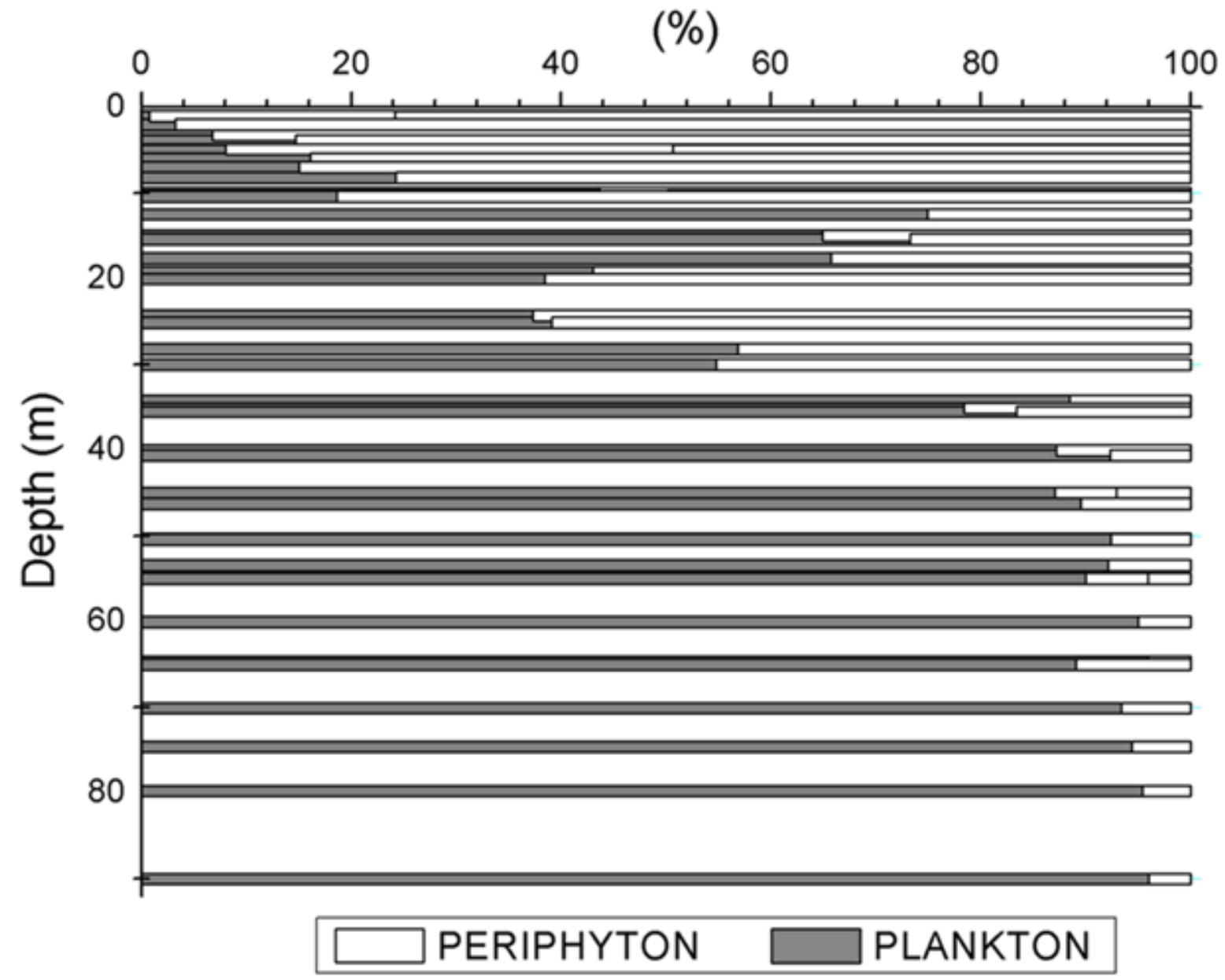

Fig. 2. Mean relative abundance (\%) of periphytic and planktonic taxa as function of sedimentary surface depths.

et al. 2001).

Diatom species optima and tolerances with respect to water depth were determined by analyzing the frequency of each species distribution along a depth gradient using the weighted averaging technique (BIRKS et al. 1990) with inverse and classical deshrinking using the program C2 version 1.5 (JugGINS 2007).

\section{Results}

\section{Physical and chemical characteristics of Lugu Lake}

The spatial variability in lake chemistry was relatively high in August 2010 (Table 1). Across the 43 sampling sites, $\mathrm{pH}$ ranged from 8.47 to 9.33 (mean $=9.08)$. Large differences of 2 to $\sim 210$ $\mu \mathrm{S} . \mathrm{cm}^{-2}$ in conductivity were recorded. Lake temperatures were relatively high with values ranging from 18.7 to $22.5^{\circ} \mathrm{C}$ (mean $=21.3^{\circ} \mathrm{C}$ ). A significant correlation between water temperature and Chl- $a$ was evident (Table 2). Lugu Lake had TP concentrations ranging from 19 to $87 \mu \mathrm{g} . \mathrm{l}^{-1}$ (mean $=50 \mu \mathrm{g} . \mathrm{l}^{-1}$ ) and TN concentrations ranging from 80 to $309 \mu \mathrm{g} .1^{-1}$. TP exhibited a negative correlation with water depth $(\mathrm{r}=-0.419)$. Accordingly, the higher TP concentrations were restricted to the shallow water zone. Bicarbonate concentrations were higher than carbonate anions. The grain size of surface sediment had little difference along the depth gradient and LOI varied between $4 \%$ and $23 \%$.

\section{Diatom assemblages in surface sediment}

The most common diatoms in Lake Lugu were the planktonic taxa Cyclotella ocellata PANT., Cyclostephanos dubius (FRICKE) RoUnd and Asterionella formosa HASSALL. The common epiphytic species were Staurosirella pinnata (EHRENB.) Williams et Round, Pseudostaurosira brevistriata (GRUNOW) Williams et Round, Staurosira construens v. venter (EHRENB.) HAMILTON, Achnanthidium minutissimum (KÜTz.) CZARNECKI, Amphora pediculus (KÜTZ.) GRUNOW, Epithemia 







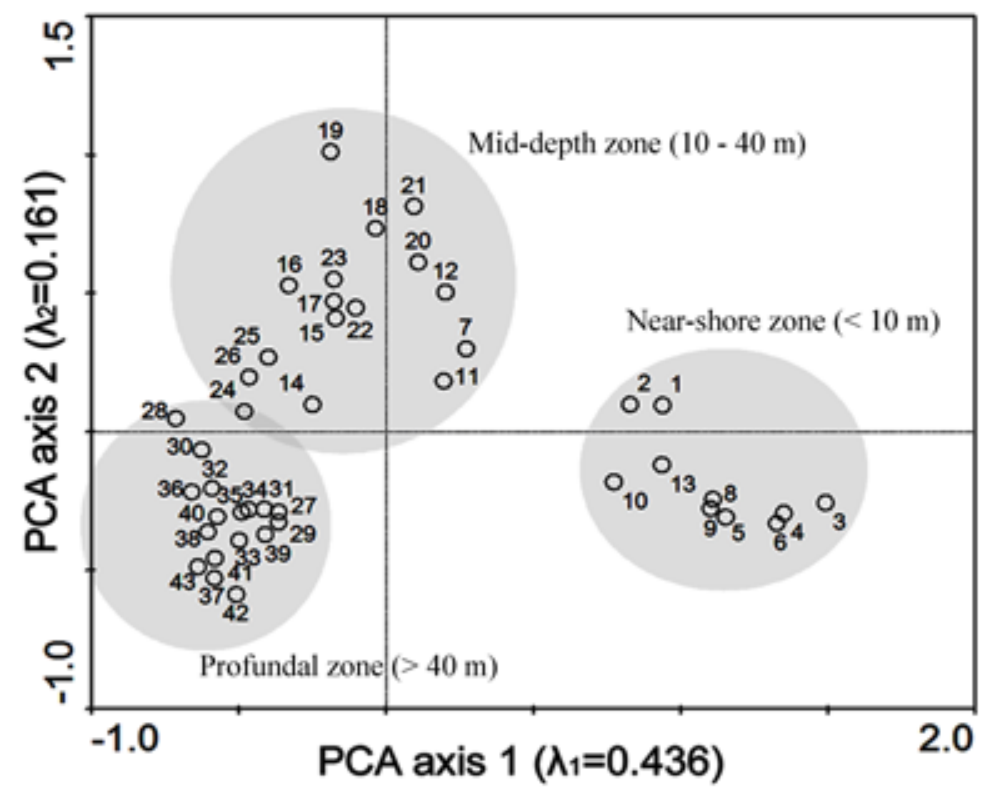

Fig. 4. PCA ordination of sample sites determined by relative community composition. Circled clusters represent sites of similarity based on water depth. Three distinct zones were identified.
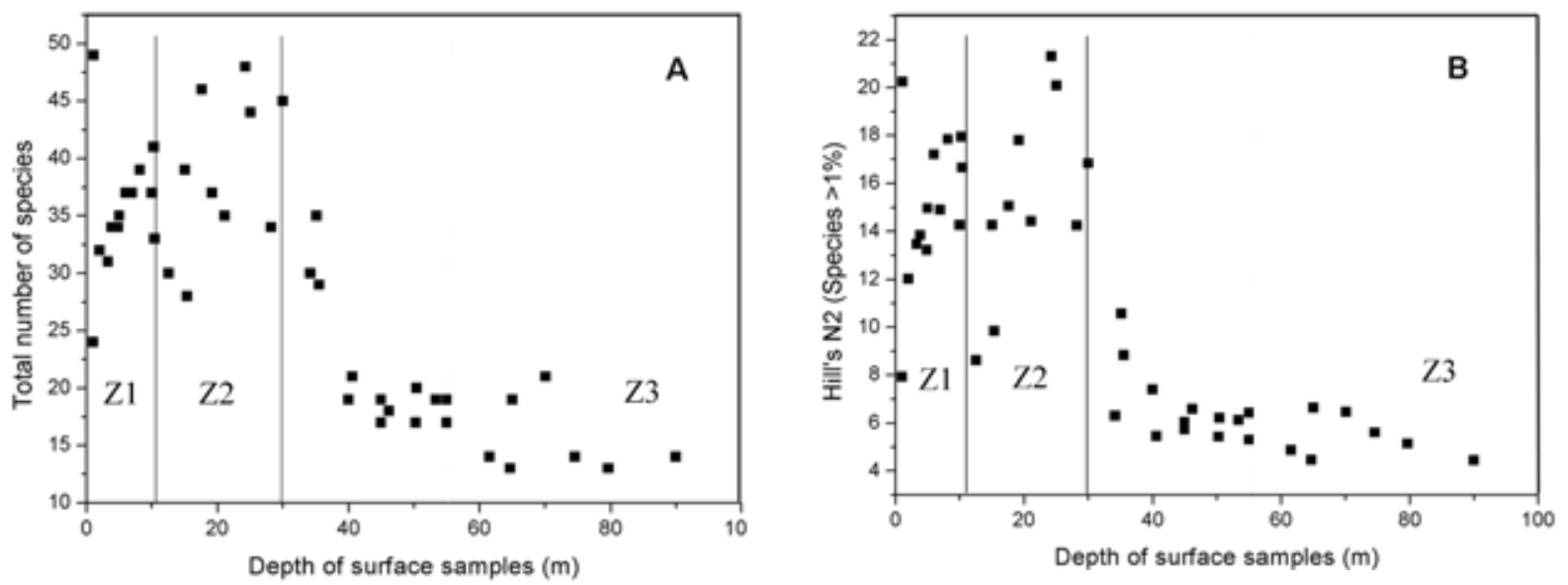

Fig. 5. Total number of species (species richness) (A) and the species evenness represented by Hill's N2 (B) for Lake Lugu. The vertical bars on the graphs are based on a depth-constrained cluster analysis. Zone $\mathrm{Z} 1$ is the littoral benthic region, zone $\mathrm{Z} 2$ is the mid-depth region, and zone Z3 represents the pelagic planktonic.

sorex KüTz. and epipelic taxa within Diploneis (Ehrenb.) Cleve. Of these, C. ocellata was consistently more abundant in the plankton-dominated samples, and Staurosirella pinnata in the non-plankton dominated samples.

\section{Spatial patterns of diatom assemblages in sur- face sediments}

The percentages of planktonic and periphytic taxa varied with increasing water depth (Fig. 2). Three distinct groups of diatom assemblages were identified through the results of a constrained cluster analysis which correspond closely to the zones defined by PCA (Figs 3, 4). Benthic sediments of depth $<10 \mathrm{~m}$ close to the shore (near-shore, Zone
Z1) were dominated by periphytic taxa (80-90\%) consisting primarily of small araphid species $(P$. brevistriata, $S$. construens v. venter and S. pinna$t a$ ). In addition the proportion of other periphytic taxa such as A. minutissimum, Am. pediculus, $E$. sorex, Navicula cryptotenella LANGE-BERT. and Nitzschia fonticola (GRUNOw) GRUNOw were common in the shallower near-shore areas of the lake. A. minutissimum reached peak abundance around $10 \mathrm{~m}$. The samples grouped in the zone ranging from 10 to $40 \mathrm{~m}$ (mid-depth zone, Zone Z2), were characterized by the dominance of the planktonic taxon C.ocellata and epipelic taxa within the genus Diploneis. The percentages of $C$. ocellata and A. formosa were higher than $\mathrm{Z} 1$ and the epipelic 

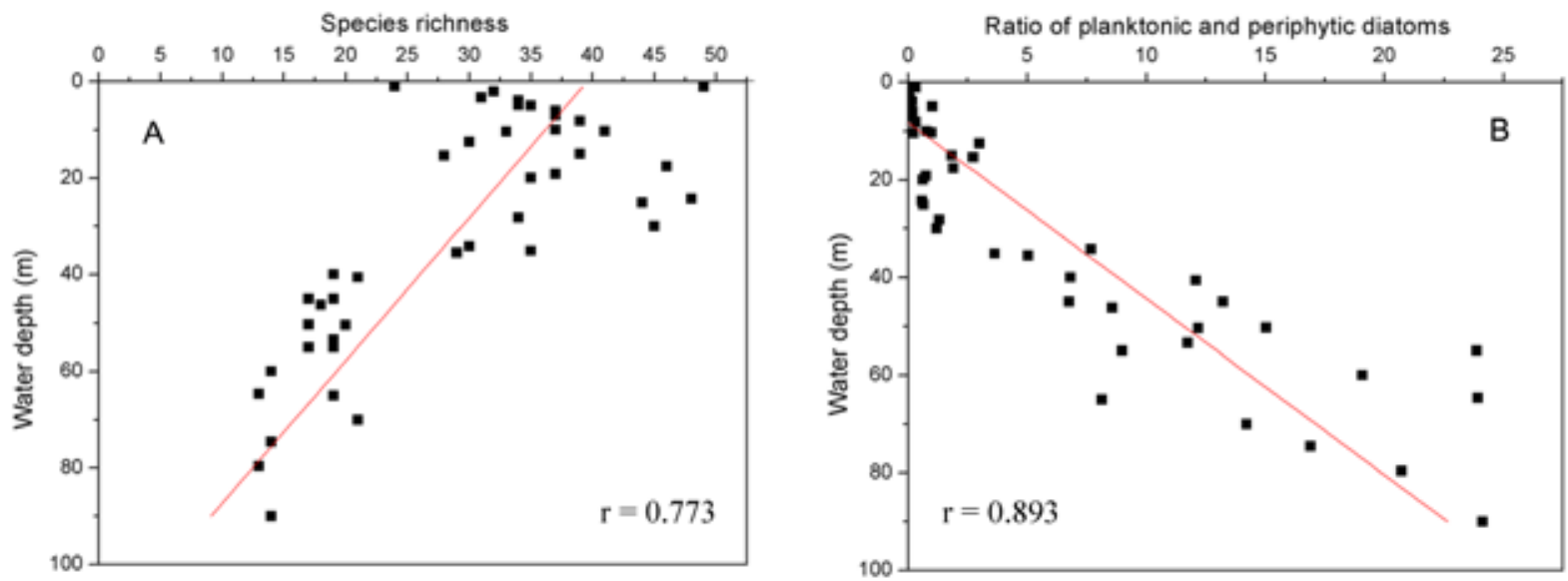

Fig. 6. The relationship between the lake water depth and species richness (A) and the ratio of planktonic to periphytic diatoms (B) in surface-sediment samples from Lugu Lake.

species Diploneis spp. peaked in relative abundance. Periphytic taxa such as $S$. pinnata and $P$. brevistriata declined relative to Z1. Samples from the deep pelagic zone $>40 \mathrm{~m}$ (Zone Z3), were mainly dominated by euplanktonic species (Fig. 3). The major species were $C$. ocellata, and A. formosa. The abundance of $C y$. dubius was high at depths greater than $35 \mathrm{~m}$ reaching a maximum abundance between $5 \%$ to $18 \%$ in this zone. In the deepest waters $(>60 \mathrm{~m})$ planktonic diatoms such as C. ocellata, A. formosa and Cy. dubius dominated the assemblage. In particular, the relative abundance of $C y$. dubius increased. From the deeper profundal zone to the shallower near-shore zone, the diatoms changed from planktonic assemblages, composed primarily of $C$. ocellata, $C y . d u$ bius and $A$. formosa, to an assemblage dominated by epiphytic taxa (Fig. 3).

\section{Species diversity, richness and evenness}

Species richness (total number of species) and species evenness (Hill's N2) were examined across the water-depth gradient. It was found that the total number of species (species richness) of diatoms was highest in samples collected in the littoral and mid-depth zones where the water depth was less than $30 \mathrm{~m}$ (Zones Z1 \& Z2), with an average of 30-50 species (Fig. 5A). The number of species was lower in the planktonic zone $(>30 \mathrm{~m}$, $13-35$ species, Zone Z3), with an average number of species ranging from 17 to 35 between 34 and $55 \mathrm{~m}$ and declining to an average of 13-21 taxa at depths $\geq 60 \mathrm{~m}$. Overall, the pattern of species richness was one of a gradual progression from high to low as the zones changed from near-shore into deeper waters, which was correlated with water depth (Fig. 6A).

Species evenness, represented by Hill's N2, was highest in Zone 2 reaching an average of 21.3 between 12.5 and $30 \mathrm{~m}$ (Fig. 5B), declined at a depth of $34 \mathrm{~m}$ with an average of 5.3-10.6 and reached the lowest values at depths $\geq 60 \mathrm{~m}$. This indicated a similar pattern to that observed in the species richness, with higher evenness in the benthic zone and mid-depth zone when compared to the planktonic zone. Species diversity decreased with the increase in water depth (Fig. 6A). The ratio of planktonic and periphytic diatom assemblages in the surface sediments increased from the littoral to the deep water zone (Fig. 6B).

\section{Optima and tolerances of diatom species with sedimentary surface depths}

In the DCA ordination, eigenvalues of the first two axes were $\lambda_{1}=0.216$ and $\lambda_{2}=0.169$, and accounted for $38.5 \%$ of the variance. The gradient length of the first DCA axis was 1.99 (standard deviation (S. D.) units) and the second axis was 1.77 S. D. which indicated that techniques based on linear species distribution were the most appropriate.

In order to determine environmental and diatom community relationships a RDA was used. In this RDA, the first $\left(\lambda_{1}=0.387\right)$ and the second $\left(\lambda_{2}=0.095\right)$ RDA axes explained $48.2 \%$ of the total variance in the diatom data (Fig. 7). The species-environment correlations were high for both axis $1(0.948)$ and axis $2(0.802)$, and accounted for $83.7 \%$ of the species-environment relations, which demonstrated a strong correlation between the environmental variables and species included in the RDA. Only three variables (water depth, LOI and TP) had significant $(\mathrm{P} \leq 0.05)$ explanatory 




Fig.7. Redundancy Analysis (RDA) results showing relationships between environmental variables and diatom taxa distribution $(p \leq 0.05)$. Taxa shown in the diagrams were found at least once in $>1 \%$ abundance. Diatom taxa: (Ach-cur) Psammothidium curtissimum (CARTER) ABOAL; (Ach-min) Achnanthidium minutissimum (KÜTz.) CZARn.; (Ach-zie) Platessa ziegleri (LANGEBert.) Lange-Bert.; (Amp-ina) Amphora inariensis Krammer; (Amp-lib) Amphora copulata (Kütz.) Schoeman et R.E.M. Archibald; (Amp-ped) Amphora pediculus (Kütz.) Grunow; (Ast-for) Asterionella formosa Hassall; (Cam-hib) Campylodiscus hibernicus Ehrenb.; (Coc-plli) Cocconeis placentula v. lineata (Ehrenb.) VAn Heurck; (Cyc-oce) Cyclotella ocellata Pant.; (Cyc-rho) Cyclotella rhomboideo-elliptica Skuja; (Cycs-dub) Cyclostephanos dubius (Fricke) Round; (Cym-micr) Encyonopsis microcephala (Grunow) Krammer; (Dip-ell) Diploneis elliptica (KÜTZ.) ClevE; (Dip-oblo) Diploneis oblongella (Nägeli ex Kütz.) Ross; (Dip-ocu) Diploneis oculata (BréB.) Cleve; (Dip-pet) Diploneis petersenii Hustedt; (Epi-adn) Epithemia adnata (Kütz.) BRÉв.; (Epi-sor) Epithemia sorex Kütz.; (Fra-cap) Fragilaria capucina Desm.; (Fra-cape) Fragilaria capucina v. perminuta (Grunow) LANGE-Bert.; (Fra-ten) Fragilaria tenera (W. SM.) LANGE-BerT.; (Gom-ang) Gomphonema angustatum (Kütz.) RABENH.; (Gom-sub) Gomphonema subtile EhrenB.; (Gyr-accu) Gyrosigma accuminatum (Kütz.) RABenH.; (Nav-cos) Hippodonta costulata (Grunow) Lange-Bert., Metzeltin et WitKowski; (Nav-cryc) Navicula cryptocephala KütZ.; (Nav-cryt) Navicula cryptotenella Lange-Bert.; (Nav-exi) Navicula exigua (W.Greg.) Grunow; (Nav-luc) Fallacia lucinensis (Hust.) D.G.MAnN; (Nav-rad) Navicula radiosa Kütz.; (Nav-rhy) Navicula rhynchocephala v. biceps (EHRENB.) Grunow; (Nav-sal) Navicula salinarum Grunow; (Nav-prae) Navicula praeterita Hust.; (Nav-sunu) Eolimna subminuscula (Manguin) Gert Moser, Lange-Bert. et Metzeltin; (Nav-subr) Navicula subrotundata Hust.; (Nav-tene) Navicula tenelloides Hust.; (Nav-vir) Navicula viridula (Kütz.) Ehrenb.; (Nav-vita) Navicula vitabunda Hust.; (Nei-pro) Neidium productum (W. Sm.) Cleve; (Nit-ang) Nitzschia angustata (W. Sm.) Grunow; (Nit-anla) Nitzschia angustatula Lange-Bert.; (Nit-didi) Nitzschia dissipata v. dissipata (Kütz.) Rabenh.; (Nit-dime) Nitzschia dissipata v. media (Hantzsch) Grunow; (Nit-fle) Nitzschia flexoides Geitler; (Nit-fon) Nitzschia fonticola (Grunow) Grunow; (Nit-gra) Nitzschia gracilis Hantzsch; (Nit-pal) Nitzschia paleacea Grunow; (Pse-bre) Pseudostaurosira brevistriata (Grunow) Williams et Round; (Rho-gib) Rhopalodia gibba (Ehrenb.) O.Müll.; (Sta-cove) Staurosira construens v. venter (Ehrenb.) Hamilton; (Sta-pin) Staurosirella pinnata (Ehrenb.) Williams et Round; (Suri-lin) Surirella linearis W. Sm.

powers (Fig. 7). There was a clear negative depth gradient correlated with Axis $1(\mathrm{r}=-0.92)$. TP was positively correlated with Axis $1(\mathrm{r}=0.50)$, while percent organic content (LOI) showed a negative correlation $(\mathrm{r}=-0.40)$ with axis 2 .

Water depth optima and tolerances for 53 diatom taxa were developed using weighted averaging (WA). A strong correlation was found between measured and inferred water depth using a linear WA regression model (Fig. 8). Species known to be planktonic had depth optimum over $28 \mathrm{~m}$ (except Cyclotella rhomboideo-elliptica), and the most abundant periphytic taxa (S. pinnata, $P$. brevistriata, $S$. construens v. venter) had infer- 

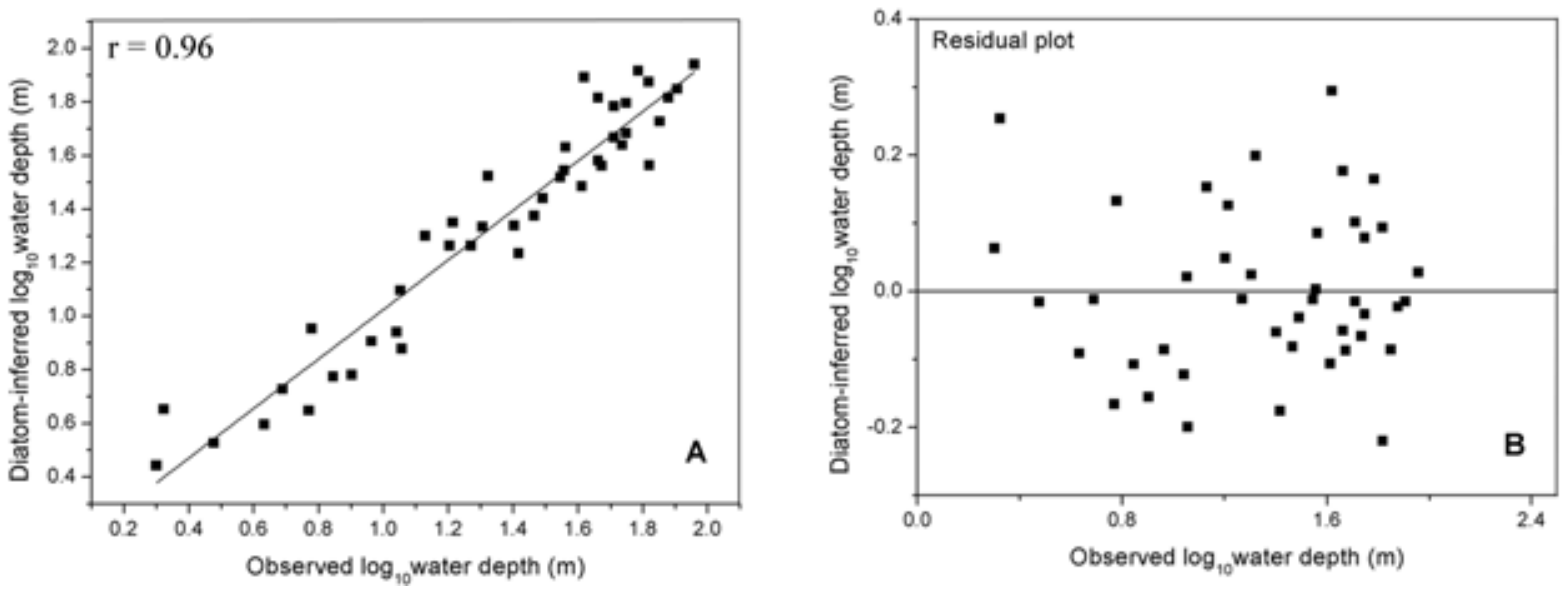

Fig. 8. Plots of observed $\log _{10}$ water depth, versus diatom-inferred $\log _{10}$ water depth and plots of observed $\log _{10}$ water depth, versus residual $\log _{10}$ water depth, based on weighted-averaging regression and calibration models.

red depth optima shallower than $11 \mathrm{~m}$. The most abundant planktonic taxa C. ocellata, A. formosa and $C y$. dubius showed the highest weighted-average depth-optima estimates $(28 \mathrm{~m}, 33 \mathrm{~m}$ and 36 m, respectively; Fig. 9). Thirty taxa representing 10 genera had water-depth optima estimates in the range of 11-30 m. Water depth optima $<11$ $\mathrm{m}$ were represented by 19 taxa in 11 genera. The lowest water-depth optima estimates were for Platessa ziegleri (LANGe-Bert.) LAnge-Bert. (3.2 m), Neidium productum (4.6 m) and Surirella linearis W. SM. (5.1 m).

\section{Discussion}

\section{Depth and diatom assemblage compositions}

Published studies have shown the importance of lake water depth as an environmental driver structuring living diatom communities (STONE \& Fritz 2004; Angeli \& CANTONATI 2005; CAntonati et al. 2009). The bathymetry of a lake is key to determining the diatom community structure in relation to depth. Differences in water depth exert a strong influence on the geochemical composition of surface sediments, with resulting distinct changes in the microhabitat (LEIRA \& CANTONATI 2008). These benthic microhabitats are influenced by light conditions, water temperature, nutrients and physical characteristics like grain size and organic matter (\%). Limnological studies have shown that diatom assemblages can change in a sequential manner from the near-shore littoral zone to the deep profundal zone along a gradient of water depth (e.g. Stone \& Fritz 2004; CANTONATI et al. 2009; LAIRD et al. 2010; PUUSEPP \& PUN-
NING 2011). Our study indicated a similar pattern in species distributions across the water-depth gradient, with some species having a significant shallower $(<10 \mathrm{~m})$ or mid-depth $(10-30 \mathrm{~m})$ zone distributions, whereas others showed a clear distribution in the deeper zone. For example, a number of araphid species reached abundances $>10 \%$ only in samples from $<10 \mathrm{~m}$ depth (e.g. S. pinnata, $P$. brevistriata, S. construens v. venter). These araphid taxa have been identified as having a preference for shallow waters (Hustedt 1930; DougLas \& SMOL 1995), whereas actively motile taxa (e.g. Navicula sensu lato and Nitzschia spp.) exhibited a deeper zone preference (HoAgland \& Peterson 1990). Periphytic taxa, occurring within a number of microhabitats, dominated the near-shore zone, and likely influenced by light intensity, increased wave action, and heterogeneous substrates (STEvenson \& Stoermer 1981; Hoagland \& Peterson 1990; Cantonati et al. 2009). The most dominant taxon in the near-shore zone was $S$. pinnata (53\%) which colonized the bottom sediments of waters with varying conditions of fluctuating physical or chemical characteristics (GRIFFITHs et al. 2002; Punning \& Puusepr 2007). The mid-depth zone (Z2) was characterized by reduced light, and less substrate area compared to the near-shore zone. Periphytic taxa valves decreased to $0.3-2 \%$, while the valves of planktonic taxa $C$. ocellata, and $A$. formosa were dominant. However, in this zone, the benthic taxa Diploneis spp. (D. elliptica (Kütz.) Cleve, D. oblongella (Nägeli ex Kütz.) Ross, D. oculata (BRÉB.) ClEVE) increased in relative abundance which indicated the functional importance of mobility within this zone (STEVENSON $\&$ STOERMER 1981). The dominance of sedimented 


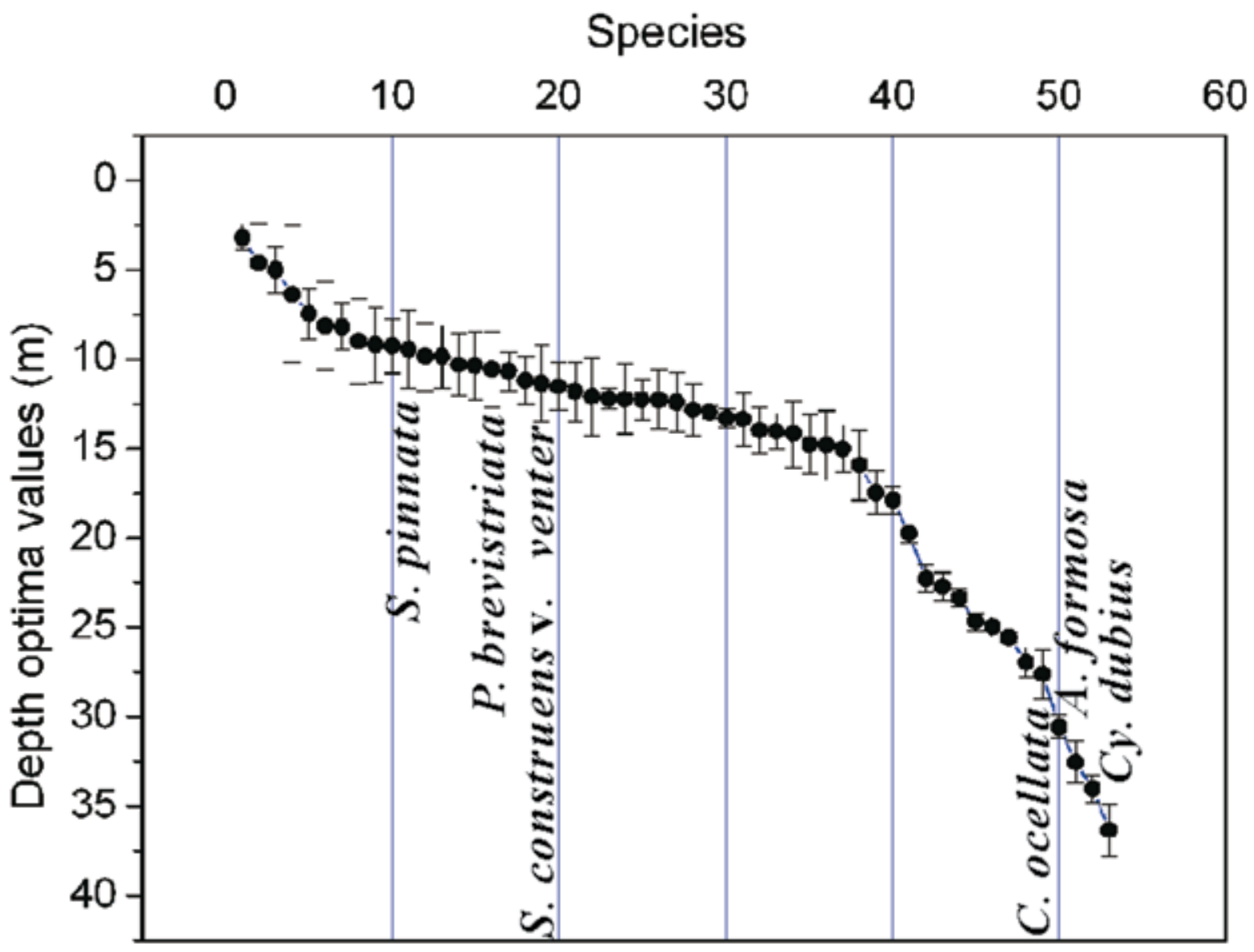

Fig. 9. Species optima for water depth estimated by weighted averaging. The dominant taxa labeled. Diatom taxa with codes: (1-10) Platessa ziegleri, Neidium productum, Surirella linearis, Cyclotella rhomboideo-elliptica, Navicula exigua, Fragilaria capucina v. perminuta, Gomphonema subtile, Cocconeis placentula v. lineata, Navicula subrotundata, Gomphonema angustatum; (11-20) Staurosirella pinnata, Nitzschia dissipata v. dissipata, Nitzschia fonticola, Rhopalodia gibba, Gyrosigma accuminatum, Pseudostaurosira brevistriata, Amphora copulata, Nitzschia angustata, Staurosira construens v. venter, Navicula viridula; (21-30) Navicula cryptotenella, Encyonopsis microcephala, Navicula radiosa, Amphora pediculus, Navicula salinarum, Psammothidium curtissimum, Fragilaria capucina, Nitzschia paleacea, Nitzschia gracilis, Navicula cryptocephala; (31-40) Nitzschia dissipata v. media, Nitzschia angustatula, Navicula tenelloides, Achnanthidium minutissimum, Epithemia sorex, Eolimna subminuscula, Fragilaria tenera, Epithemia adnata, Nitzschia flexoides, Navicula rhynchocephala; (41-50) Navicula praeterita, Diploneis oculata, Navicula vitabunda, Diploneis oblongella, Diploneis elliptica, Amphora inariensis, Campylodiscus hibernicus, Hippodonta costulata, Cyclotella ocellata, Fallacia lucinensis; (51-53) Asterionella formosa, Diploneis petersenii, Cyclostephanos dubius.

valves from planktonic species like C. ocellata, Cy. dubius, and A. formosa in the deep water anoxic sediments (e.g. Lugu Lake, Zone 3) have been well documented (REYNOLDS 1984).

Within the water column, TP was negatively correlated with water depth. The association between TP and diatom growth has been well documented in limnological studies (REYNOLDS 1984) as well as modern sediment diatom data sets (e.g. LotTer et al. 1997; Bigler et al. 2006) and lake paleo-sediment records (e.g. LotTeR 1998). In this study, benthic shallow water species were not observed in the deep water sediments, and planktonic diatoms were not abundant in the shallow waters $(<11 \mathrm{~m})$. The consistency of water depth as an explanatory variable, confirmed by direct gradient analysis, indicated that physical disturbances within the littoral zone, if present, were not significantly redistributing the littoral taxa into the deep water zones, although the gravitational redistribution of littoral taxa towards the deep water basin was evident in zone 2 . In contrast, the open-water planktonic flora was not mixing in a significant way with the shallow littoral waters. The stability in sediment diatom assemblage compositions among the zones establishes the future use of diatom-depth proxies for interpreting temporal water level changes within Lake Lugu. 


\section{Species diversity}

Species richness (total number of species) and species evenness (Hill's N2) were chosen to evaluate species diversity in this study. Species diversity decreased with the increase in water depth which is the result of decreased habitat diversity in the profundal area (Moos et al. 2005; Wolin \& STONE 2010) (Fig. 5B). In shallower areas, the increase in microhabitats (e.g. substrates, such as sand, stones, mud) and aquatic macrophytes growth supported diatom taxa with many different life history strategies which results in the co-existence of more species (CABALlERO et al. 2002). The depth to which light penetrated exerted a strong effect on microhabitat availability and the growth of species. Light is a major regulator of photosynthesis (REYNOLDS 1984) controlling the co-existence of diatom species in the shallow water due to the greater variation in light quality and quantity (Moos et al. 2005). Compared to the deep zone, higher species richness and evenness in the near-shore and mid-depth zone observed in this study, are similar to the results by ANGELI \& Cantonati (2005), Moos et al. (2005), Punning \& Puusepp (2007) and Cantonati et al. (2009).

\section{Species optima and tolerances}

Water depth, organic matter and TP within the water column above the benthic sample site, were found to explain the greatest amount of variation in our sediment diatom data. While these variables were identified as significant, they only account for $\sim 48.2 \%$ of the total variation in species assemblage. The changing microhabitats from benthic to pelagic, in comparison with a selected set of surface water chemistry variables can account for the low $<50 \%$ explained variance in the diatom sediment assemblages. For example, previous studies have identified disturbance factors, such as wave action (not measured here) as primary factors impacting on diatom sediment assemblages (Stevenson \& Stoermer 1981; Hoagland \& PeTERSON 1990). In addition, light plays an important role in driving algal productivity and determining species composition in lakes (REYNOLDS 1984). Light penetration is a controlling factor governing the maximum depth of benthic taxa (LAIRD et al. 2011). Therefore light penetration has been clearly defined as a major factor in defining the distinct zone between littoral and planktonic diatom assemblages (CANTONATI et al. 2009). The clear distinction between pelagic waters and the near-shore littoral zone would suggest that who- le lake mixing is limited or that the productivity of the pelagic waters exceeds that of the littoral zone, and the benthic productivity is largely dependent on the depth to which the incident light penetrates. The large pelagic water volume relative to littorals waters would further suggest that planktonic species will dominate the deep water anoxic benthic sediments.

Depth optima for the prominent taxa show that the diatom composition in the sediments changed from the near-shore littoral zone to the deep profundal zone along a gradient of water depth. In particular, abundant taxa $S$. pinnata, $P$. brevistriata, F. capucina v. perminuta and $S$. construens v. venter were identified as shallow water taxa. The weighted average (optimum) depth values for S. pinnata $(9.4 \mathrm{~m})$ and $P$. brevistriata $(11$ $\mathrm{m})$ were not in agreement with the depth optima listed by YANG \& DuthiE (1995), between 4-5 m, however the optima for S. pinnata did correspond with a depth optimum of 8.2-11.5 m presented by LAIRD et al. (2011). Depth optima can also vary for the same taxa, due to physical factors such as disturbance and sediment migration, or more likely to microhabitat availability, light and different chemical and physical characteristics of the lake. The planktonic taxa $C$. ocellata, A. formosa and $C y$. dubius preferred deep waters with the highest calculated depth optima (28, 33 and $36 \mathrm{~m}$, respectively). All the planktonic species in this study can be classified as eutrophic taxa (ANDERSON 1990, 1997; ANDERSON et al. 1993; HÁKANSSON \& Regnell 1993; Bradshaw et al. 2005).

\section{Conclusions and implications for palaeolimno- logical study}

This study found a strong relationship between the spatial distribution of surface sediment diatom assemblages and lake depth, in a subtropical deep-water lake. Three major benthic zones based on the composition of diatom assemblages were identified from the near-shore to deep waters of Lugu Lake: i) a near-shore assemblage of araphid species and other periphytic taxa (Achnanthidium, Amphora, Epithemia, Nitzschia, Navicula sensu lato); ii) a mid-depth planktonic (C. ocellata, $A$. formosa)/ epipelic taxa (Diploneis spp.) zone; and iii) a deep-water anoxic planktonic zone. The results showed water depth to be the dominant factor governing the sediment diatom (living and dead frustules) composition in this lake. TP and LOI (proxy for organic matter) were also identified as factors determining diatom assemblages in the 
photic zones, but not as important as water depth. Further, the results indicate 1) sedimentation in the littoral zones were not significantly impacted by open waters and physical factors attempting to mix the waters and sediments and 2) coring deep water sediments will consistently highlight pelagic production, which limits the assessment of littoral microhabitat diversity and ultimately paleo-reconstructions showing minimal to moderate lake level changes. In Lugu Lake, deep-water diatom assemblages were dominated by C. ocellata, A. formosa, Cy. dubius which are indicators of mesotrophic to eutrophic pelagic waters. Littoral benthic assemblages were dominated by araphid diatoms typically associated with disturbance or changing habitats. The diatom assemblage and distribution pattern was similar to other lakes across three continents reported in the literature, which suggests that the physical, chemical and weather related stressors on the limnology of the lakes are similar. This study provides theoretical support for the use of water depth as a reconstruction variable in hindcasting paleo-limnological and paleo-climatic conditions in Lugu Lake which is affected by the Asian Southwest monsoon.

\section{Acknowledgement}

We are grateful to $\mathrm{Xu}$ Chen, Min Yao, and Zhujun $\mathrm{Hu}$ (Nanjing Institute of Geography and Limnology, Chinese Academy of Sciences) for field assistance. We also thank two anonymous reviewers who gave us important advice that let us improve the quality of the manuscript. This research was supported by the National Basic Research Program of China (2010CB950201).

\section{References}

ANDERson, N.J. (1990): Spatial pattern of recent sediment and diatom accumulation in a small, monomictic eutrophic lake. - J. Paleolimnol. 3: 143-160.

Anderson, N.J. (1997): Reconstructing historical phosphorous concentrations in rural lakes using diatom models. - In: TunNey, H.; CARTON, O.T.; Brookes, P.C. \& Johnston, A.E. (eds): Phosphorus Loss from Soil to Water. - pp. 95-118, CAB International, Wallingford, UK.

Anderson, N.J.; Rippey, B. \& Gibson, E. (1993): A comparison of sedimentary and diatom-inferred phosphorus profiles: implications for defining predisturbance nutrient conditions. - Hydrobiologia 253: 357-366.

Angeli, N. \& Cantonati, M. (2005): Depth-distribution of surface sediment diatoms in Lake To- vel, Italy. - Verh. Internat.Verein. Limnol. 29: 539-544.

Barker, P. A.; Roberts, N.; Lamb, H. F.; VAn der KaArs, S. \& Benkaddour, A. (1994): Interpretation of Holocene lake-level changes from diatom assemblages in Lake Sidi Ali, Middle Atlas, Morocco. - J. Paleolimnol. 12: 223-234.

Battarbee, W. (1986): Diatom analysis. - In: BerGLunD, B.E. (ed.): Handbook of Holocene Palaeoecology and Palaeohydrology. - pp. 527-570, Wiley Interscience, Chichester, UK.

Bigler, C.; Barnekow, L.; Heinrichs, M.L. \& Hall, R.I. (2006): Holocene environmental history of Lake Vuolep Njakajaure (Abisko National Park, northern Sweden) reconstructed using biological proxy indicators. - Veg. Hist. Archaeobot. 15:309-320.

BIRKs, H.J.B. (1995): Quantitative palaeoenvironmental reconstructions. - In: MADDY, D. \& BREW, J.J. (eds): Statistical Modeling of Quaternary Science Data. - pp. 161-254, Quaternary Research Association, Cambridge.

Birks, H.J.B.; Juggins, S. \& Line, J.M. (1990): Lake surface-water chemistry reconstructions from paleolimnological data. - In: MAson, B. J. (ed.): The Surface Waters Acidification Programme. - pp. 301-311, Cambridge University Press, Cambridge.

Bradshaw, E.G.; Rasmussen, P.; Nielsen, H. \& AnDERSON, N.J. (2005): Mid- to late-Holocene land-use change and lake development at DallundSø, Denmark: trends in lake primary production as reflected by algal and macrophyte remains. - The Holocene 20: 1130-1142.

Brugam, R. B.; Mckeever, K. \& Kolesa, L. (1998): A diatom-inferred water depth reconstruction for an Upper Peninsula, Michigan, lake. - J. Paleolimnol. 20: 267-276.

Caballero, M.; Ortega, B.; Valadez, F.; Metcalfe, S.; Macias, J. L. \& Sugiura, Y. (2002): Sta. CRUZ ATIZAPAN: a 22-ka lake level record and climatic implications for the late Holocene human occupation in the Upper Lerma Basin, Central Mexico. - Palaeogeogr. Palaeoclimatol. Palaeoecol. 186: 217-235.

Cantonati, M.; Scola, S.; Angeli, N.; Guella, G. \& Frassanito, R. (2009): Environmental controls of epilithic diatom depth-distribution in an oligotrophic lake characterized by marked waterlevel fluctuations. - Eur. J. Phycol. 44: 15-29.

Douglas, M.S.V. \& Smol, J.P. (1995): Periphytic diatom assemblages from high Arctic ponds. - J. Phycol. 31: 60-69.

Fourtanier, E. \& Kociolek, J.P. (2011): Catalogue of diatom names. - Academy of Science - California. [Online] http://research.calacademy.org/ research/diatoms/ names/index.asp

Goswami, B.N. \& Ajayamohan, R.S. (2001): Intrasea- 
sonal oscillations and interannual variability of the Indian summer monsoon. - J. Climate. 14: 1180-1198.

Griffiths, H. I.; Reed, J. M.; Leng, M. J.; Ryan, S. \& Petkovski, S. (2002): The conservation status and recent palaeoecology of Balkan Lake Dojran. - Biol. Conserv. 104: 35-49.

GrimM, E.C. (1990): TILIA and TILIA GRAPH. PC spreadsheet and graphics software for pollen data. INQUA, Working Group on Data-Handling Methods. - Newsletter. 4: 5-7.

Grimm, E.C. (2004): TGView. - Illinois State Museum Research Collection Center, Spring-field.

HÅkansson, H. \& Regnell, J. (1993): Diatom succession related to land use during the last 6000 years: a study of a small eutrophic lake in southern Sweden. - J. Paleolimnol. 8: 49-69.

Hall, R.I. \& Smol, J.P. (2010): Diatoms as indicators of lake eutrophication. - In: SMOL, J.P. \& STOERMER, E.F. (eds): The Diatoms: Applications for the Environmental and Earth Sciences $2^{\text {nd }}$ edition. - pp. 122-151, Cambridge University Press, Cambridge.

Hammer, Ø.; Harper, D.A.T. \& Ryan, P.D. (2001): PAST: paleontological statistics software package for education and data analysis. - Palaeontol. Electronica. 4. [Online] http://palaeo-electronica.org/2001 1/past/issue 1 01.htm.

Heiri, O.; Lotter, A.F. \& Lemcke, G. (2001): Loss on ignition as a method for estimating organic and carbonate content in sediments: reproducibility and comparability of results. - J. Paleolimnol. 25: 101-110.

Hoagland, K.D. \& Peterson, C.G. (1990): Effects of light and wave disturbance on vertical zonation of attached microalgae in a large reservoir. $-\mathrm{J}$. Phycol. 26: 450-457.

Hustedt, F. (1930): Bacillariophyta (Diatomeae). - In: PAscher, A. (ed.): Die Süsswasser-Flora Mitteleuropas 10. - 466 pp., Gustav Fischer - Jena.

JI, J. \& FAN, Y.Q. (1983): Preliminary analysis on the hydrologic characteristics of Lake Lugu. - In: The Comprehensive Scientific Expedition to the Qinghai-Xizang Plateau, Chinese Academy of Sciences. Qinghai-Xizang Plateau Research, Hengduan Mountains Expedition. Series One. pp. 214-225, Kunming: Yunnan People's Publishing House.

JugGins, S. (2007): C2 Version 1.5. Software for ecological and palaeoecological data analysis and visualisation. - 73 pp., Newcastle University, UK.

Kemball-Cook, S. \& WAng, B. (2001): Equatorial waves and air-sea interaction in the boreal summer intraseasonal oscillation. - J. Climate. 14: 2923-2942.

Krammer, K. \& Lange-Bertalot, H. (1986): Bacillariophyceae. 1: Teil: Naviculaceae. - In: ETtL
H.; Gärtner, G.; Gerloff, J.; Heynig, H. \& Mollenhauer, D. (eds): Süßwasserflora von Mitteleuropa, 2/1. - 876 pp., Gustav Fischer Verlag, Stuttgart - Jena.

Krammer, K. \& Lange-Bertalot, H. (1988): Bacillariophyceae. 2: Teil: Bacillariaceae, Epithmiaceae, Surirellaceae. - In: Ettl H.; GÄrtner, G.; Gerloff, J.; Heynig, H. \& Mollenhauer, D. (eds): Süßwasserflora von Mitteleuropa, 2/2. - 596 pp., Gustav Fischer Verlag, Stuttgart Jena.

Krammer, K. \& Lange-Bertalot, H. (1991a): Bacillariophyceae. 3: Teil: Centrales, Fragilariaceae, Eunotiaceae. Unter Mitarbeit von H. Håkannson und M. Nörpel. - In: EtTl, H.; GÄrTNER, G.; Gerloff, J.; Heynig, H. \& Mollenhauer, D. (eds): Süßwasserflora von Mitteleuropa, 2/3. - 576 pp., Gustav Fischer Verlag, Stuttgart Jena.

Krammer, K. \& Lange-Bertalot, H. (1991b): Bacillariophyceae. 4: Teil: Achnanthaceae, Kritische Erganzungen zu Navicula (Lineolatae) und Gomphonema Gesamtliteraturverzeichnis. - In: Ettr, H.; Gärtner, G.; Gerloff, J.; Heynig, H. \& Mollenhauer, D. (eds): Süßwasserflora von Mitteleuropa, 2/4. - 437 pp., Gustav Fischer Verlag, Stuttgart - Jena.

Laird, K.R.; Kingsbury, M.V. \& Cumming, B.F. (2010): Diatom habitats, species diversity and water-depth inference models across surfacesediment transects in Worth Lake, northwestern Ontario, Canada. - J. Paleolimnol. 44: 10091024.

Laird, K.R.; Kingsbury, M.V.; Lewis, C.F.M. \& CuMMING, B.F. (2011): Diatom inferred depth models in 8 Canadian boreal lakes: inferred changes in the benthic:planktonic depth boundary and implication for assessment of past droughts. - Quat. Sci. Rev. 30: 1201-1217.

Leira, M. \& CANTONATI, M. (2008): Effects of waterlevel fluctuatons on lakes: an annotated bibliography. - Hydrobiologia 613: 171-184.

LotTer, A.F. (1998): The recent eutrophication of Baldeggersee (Switzerland) as assessed by fossil diatom assemblages. - The Holocene 8: 395405.

Lotter, A.F. \& Bigler, C. (2000): Do diatoms in the Swiss Alps reflect the length of ice-cover? Aquat. Sci. 62: 125-141.

Lotter, A.F.; Birks, H.J.B.; Hofmann, W. \& MarCHETto, A. (1997): Modern diatom, cladocera, chironomid, and chrysophyte cyst assemblages as quantitative indicators for the reconstruction of past environmental conditions in the Alps. I. Climate. - J. Paleolimnol. 18: 395-420.

Moos, M.T.; LAird, K.R. \& Cumming, B.F. (2005): Diatom assemblages and water depth in Lake 239 (Experimental Lakes Area, Ontario): implicati- 
ons for paleoclimatic studies. - J. Paleolimnol. 34: 217-227.

Moser, K.A.; Korhola, A.; Weckström, J.; Blom, T.; Pienitz, R.; Smol, J.P.; Douglas, M.S.V. \& HAY, M.B. (2000): Paleohydrology inferred from diatoms in northern latitude regions. $-\mathrm{J}$. Paleolimnol. 24: 93-107.

Nguetsop, V. F.; Servant-VIldary, S. \& Servant, M. (2004): Late Holocene climatic changes in West Africa, a high resolution diatom record from equatorial Cameroon. - Quat. Sci. Rev. 23: 591-609.

PAtrick, R. \& Reimer, C.W. (1966): The diatoms of the United States 1 Fragilariaceae, Eunotiaceae, Achnanthaceae, Naviculaceae. - 668 pp., Academy of Natural Sciences Monograph 13, Philadelphia, USA.

Punning, J.M. \& Puusepp, L. (2007): Diatom assemblages in sediments of Lake Juusa, Southern Estonia with an assessment of their habitat. Hydrobiologia 586: 27-41.

Puusepp, L. \& Punning, J.M. (2011): Spatio-temporal variability of diatom assemblages in surface sediments of Lake Peipsi. - J. Great. Lakes Res. 37: 33-40.

Reynolds, C.S. (1984): The Ecology of Freshwater Plankton. - 384 pp., Cambridge University Press, Cambridge.

Sanderson, E.W.; Jaiteh, M.; LeVy, M.A.; Redford, K.H.; Wannebo, A.V. \& Woolmer, G. (2002): The Human Footprint and the Last of the Wild. - Bioscience. 52: 891-904.

Shinneman A. L. C.; Bennett, D. M.; Fritz, S. C.; Schmieder, J.; Engstrom, D. R.; Efting, A. \& Holz, J. (2010): Inferring lake depth using diatom assemblages in the shallow, seasonally variable lakes of the Nebraska Sand Hills (USA): calibration, validation, and application of a 69-lake training set. - J. Paleolimnol. 44: 443-464.

Smol, J.P. \& Stoermer, E.F. (2010): The Diatoms: Applications for the Environmental and Earth Sciences. - 667 pp., Cambridge University Press, Cambridge.

State Environmental Protection Administration (SEPA). (2002): Water and Waste water Monitoring Methods (Version 4). - Beijing: China Environmental Science Press.

Stevenson, R.J. \& Stoermer, E.F. (1981): Quantitative difference between benthic algal communities along a depth gradient in Lake Michigan. - J. Phycol. 17: 29-36.

Stone, J.R. \& Fritz, S.C. (2004): Three-dimensional modeling of lacustrine diatom habitat areas: Improving paleolimnological interpretation of planktonic:benthic ratios. - Limnol. Oceanogr. 49: 1540-1548.

Ter BraAk, C.J.F. (1995): Ordination. - In: Jongman,
R.H.G.; TER BRAAK, C.J.F. \& van TONGEREN, O.F.R. (eds): Data Analysis in Community and Landscape Ecology. - pp. 91-169, Cambridge University Press, Cambridge, UK.

Ter Braak, C.J.F. \& Prentice, I.C. (1988): A theory of gradient analysis. - Adv. Ecol. Res. 18: 221-317.

Ter Braak, C.J.F. \& Šmilauer, P. (2002): CANOCO Reference Manual and CanoDraw for Windows User's Guide: Software for Canonical Community Ordination (version 4.5). - 500 pp., Microcomputer Power - Ithaca.

WANG, S.M. \& LI, J.R. (1991): Lake sediments-an effective methods to study historical climate. Chin Sci Bull. 36: 54-56.

Wolin, J.A. \& Stone, J.R. (2010): Diatoms as indicators of water-level change in fresh-water lakes. - In: Smol, J.P. \& Stoermer, E.F. (eds): The Diatoms: Applications for the Environmental and Earth Sciences $2^{\text {nd }}$ edition. - pp. 174-185, Cambridge University Press, Cambridge.

YANG, J.R. \& Duthie, H.C. (1995): Regression and weighted averaging models relating surficial sedimentary diatom assemblages to water depth in Lake Ontario. - J. Great Lakes Res. 21: 84-94.

YANG, L.F. (1984): The preliminary study on the original classification and distribution law of lakes on the Yunnan Plateau. - Trans. Oceanol. Limnol. 1: 34-39.

Zhang, S.; XIE, X.D. \& WAN G.J. (1997): Mineralogical records and their environmental aspects of Lugu Lake, Yunnan Province. - Acta Miner. Sin. 17: 183-193.

(C) Czech Phycological Society (2012)

Received May 25, 2011

Accepted September 6, 2011 